\title{
Calibration, validation and application of AquaCrop model in irrigation scheduling for rice under northwest India
}

\author{
S. S. Sandhu ${ }^{1 *}$, S. S. Mahal ${ }^{2}$ and Prabhjyot Kaur ${ }^{3}$ \\ ${ }^{1,3}$ School of Climate Change and Agricultural Meteorology, Punjab Agricultural University, Ludhiana-143109 \\ (Punjab), INDIA \\ ${ }^{2}$ Department of Agronomy, Punjab Agricultural University, Ludhiana-143109 (Punjab), INDIA \\ *Corresponding author. E-mail: ssandhu@pau.edu
}

Received: March 21, 2015; Revised received: July 18, 2015; Accepted: September 3, 2015

\begin{abstract}
A lot of research work regarding irrigation scheduling in rice has been carried out at global level with the objective of increasing irrigation water productivity (IWP) and sustaining grain yield. Under natural conditions rain disturb the planned irrigation treatments. One way to overcome this problem is to use rain shelters which is a costly affair, crop growth simulation models offer a good scope to conduct such studies by excluding the effect of rain. Very limited studies are available where FAO's AquaCrop model has been used to develop irrigation schedule for crops. Therefore, a study was conducted using FAO AquaCrop model to develop irrigation schedule for rice having higher IWP. The model was calibrated and validated using the experimental data of field experiments conducting during 2009 and 2010, respectively. The model underestimated the above ground dry biomass at 30 days after transplanting (DAT) in the range of 21.60 to $24.85 \%$. At the time of harvest the model overestimated the above ground dry biomass within the range 11.58 to $14.34 \%$. At harvest the values of normalized root mean square error (15.54\%) suggested a good fit for the above ground dry biomass and an excellent agreement (3.34\%) between observed and model predicted grain yield. The model suggested to irrigate rice transplanted in puddled loamy sand soil on every $5^{\text {th }}$ day to get higher IWP coupled with statistically similar grain yield as obtained with daily irrigation schedule.
\end{abstract}

Keywords: Above ground dry biomass, Grain yield, Puddled rice, Water productivity

\section{INTRODUCTION}

Food security of many countries including India depends upon rice. Punjab is a major contributor to the central pool of rice and its contribution ranged from $45.3 \%$ in $1980-81$ to $29.5 \%$ in $2009-10$. The sustainability of rice production in Indian Punjab is threatened by increasing scarcity of water. In northwest part of India, rice is mostly cultivated in puddled fields with continuously ponded water and it is also one of the biggest users of world's fresh water resources (Tuong and Bouman, 2003). Rice cultivation with current practices, consumes very large quantity (1500 to 3000 $\mathrm{mm}$ ) of irrigation water (Sharma et al., 2002; Singh et $a l ., 2002)$ and its cultivation is considered as one of the most important reasons for fall in underground water table in central parts of the Indian Punjab (Singh, 2006). Therefore, there is an urgent need to produce more rice per unit of irrigation water used.

Irrigation plays most important role in increasing the productivity of rice, but the irrigation water productivity (IWP) of rice is quite low owing to its high water requirement and percolation losses. Proper scheduling of irrigation can help in saving the irrigation water considerably. Many workers have suggested to irrigate the rice after 1 - 3 days after disappearance of ponded water (Bali and Uppal, 1999; Edwin and Anal, 2008; Husain et al., 2008; Luikham et al., 2004; Parihar, 2004; Ramakrishna et al., 2007; Sandhu et al., 2012). However, some others advocated to further increase the interval between successive irrigations and suggested to irrigate rice crop after 5 days after disappearance of ponded water (Sandhu et al., 1980; Singh et al., 2008 ), irrigation on every $5^{\text {th }}$ (Katozi et al., 2009) and $7^{\text {th }}$ (Khalifa et al., 2005) day. However, under natural conditions rain disturb the planned irrigation treatments and it becomes very difficult of get the proper effect of applied irrigation treatments. One way to overcome this problem is to use rain shelters which is a costly affair. Crop growth simulation models offer a good scope to conduct such studies by excluding the effect of rain. To overcome these limitations, many workers (Benli et al., 2007; Blum, 2009; Geerts and Raes, 2009; Heng et al., 2007; Pereira et al., 2009) have suggested that crop simulation models can be a useful tool for conducting such research. Very limited studies are available where FAO's AquaCrop model has been used to develop irrigation schedule for crops. The AquaCrop, developed by the FAO is a crop water productivity simulation model and it simulates response of crop yield to water. AquaCrop model evolved from the concepts of crop yield response to 
evapotranspiration (ET) developed by Doorenbos and Kassam (1979). This model requires a few parameters and other input data to simulate the yield response to water. These parameters are explicit and mostly intuitive and the model maintains an adequate balance between accuracy, simplicity and robustness. The model is aimed for use by broad range of users like engineers, economists, extension specialists and water managers at various levels (Steduto et al., 2009). The AquaCrop model has been tested by several researchers (Baumhardt et al., 2009; Geerts et al., 2009; Heng et al., 2009; Alizadeh et al., 2010; Araya et al., 2010a; Araya et al., 2010b; Andarzian et al., 2011; Stricevic et al., 2011; Zeleke et al., 2011; Zinyengere et al., 2011; Abedinpour et al., 2012; Mkhabela and Bullock 2012) around the globe under diverse environmental conditions and their results indicate the wide applicability of the model under diverse climatic conditions. Therefore, a study was conducted, in order to verify these findings and to develop irrigation schedule with higher IWP, along with similar grain yield, by using Food and Agriculture Organisation (FAO) AquaCrop model version 3.1 Plus for rice transplanted in puddled field in northwest India.

\section{MATERIALS AND METHODS}

The field experiment was conducted at Punjab Agricultural University, Ludhiana, Punjab, India, during summer seasons of 2009 and 2010. The site is situated in Trans-Gangetic agro-climatic zone, representing the Indo-Gangetic alluvial plain at $30^{\circ} 56^{\prime} \mathrm{N}$ latitude, $75^{\circ} 52^{\prime} \mathrm{E}$ longitude and at an altitude of $247 \mathrm{~m}$ above mean sea level. The soil of the experimental field was loamy sand with slightly alkaline reaction. The soil was analyzed for organic carbon (Walkley and Black, 1934), available nitrogen (Subbiah and Asija, 1956), available phosphorus (Olsen et al., 1954) and available potassium (Merwin and Peech, 1950) and their content in $0-15 \mathrm{~cm}$ layer of soil was 0.42 per cent, 285,20 and $265 \mathrm{~kg} \mathrm{ha}^{-1}$, respectively. Soil moisture (at 0.3 and 15 bars) and bulk density were determined on a $1.50 \mathrm{~m}$ profile. Electrical conductivity and $\mathrm{pH}$ were measured for the top layers of the soil profile (Table 1). All the measurements were performed before conducting the experiments. The meteorological data was recorded at Meteorological Observatory of Punjab Agricultural

Table 1. Physical and chemical properties of soil profile of the experimental field.

\begin{tabular}{|c|c|c|c|c|c|c|c|c|}
\hline $\begin{array}{l}\text { Soil depth } \\
\text { (cm) }\end{array}$ & pH & $\begin{array}{c}\text { Sand } \\
(\%)\end{array}$ & $\begin{array}{l}\text { Silt } \\
\text { (\%) }\end{array}$ & $\begin{array}{l}\text { Clay } \\
(\%)\end{array}$ & $\begin{array}{c}E C \\
\left(d_{S} ~ m^{-1}\right)\end{array}$ & $\begin{array}{c}\text { Moisture } \\
\text { content } \\
\text { (cm) at } 0.3 \text { bar }\end{array}$ & $\begin{array}{c}\text { Moisture } \\
\text { content } \\
\text { (cm) at } 15 \text { bar }\end{array}$ & $\begin{array}{l}\text { Bulk density } \\
\quad\left(\mathrm{g} \mathrm{cm}^{-3}\right)\end{array}$ \\
\hline $0-15$ & 7.93 & 77.45 & 7.75 & 14.80 & 0.25 & 3.51 & 1.38 & 1.57 \\
\hline $15-30$ & 8.03 & 76.47 & 8.63 & 14.90 & 0.29 & 3.62 & 1.44 & 1.61 \\
\hline $30-60$ & - & - & - & - & - & 6.21 & 2.23 & 1.59 \\
\hline $60-90$ & - & - & - & - & - & 6.33 & 2.35 & 1.63 \\
\hline $90-120$ & - & - & - & - & - & 6.22 & 2.31 & 1.61 \\
\hline $120-150$ & - & - & - & - & - & 6.47 & 2.02 & 1.66 \\
\hline $150-180$ & - & - & - & - & - & 6.56 & 2.13 & 1.64 \\
\hline Total & - & - & - & - & - & 38.92 & 13.86 & Average $=1.62$ \\
\hline
\end{tabular}

Table 2. Meteorological data recorded during rice growing seasons of 2009 and 2010 (recorded at meteorological observatory, Punjab Agricultural University, Ludhiana).

\begin{tabular}{|c|c|c|c|c|c|c|}
\hline \multirow{2}{*}{ Month } & \multicolumn{2}{|c|}{ Average Air temperature $\left({ }^{\circ} \mathrm{C}\right)$} & \multirow{2}{*}{$\begin{array}{c}\text { Average rela- } \\
\text { tive humidity } \\
(\%)\end{array}$} & \multirow{2}{*}{$\begin{array}{c}\text { Total } \\
\text { rainfall } \\
(\mathrm{mm})\end{array}$} & \multirow{2}{*}{$\begin{array}{c}\text { Total pan } \\
\text { evaporation } \\
(\mathrm{mm})\end{array}$} & \multirow{2}{*}{$\begin{array}{c}\text { Average sun- } \\
\text { shine hours (hr } \\
\left.\text { day }^{-1}\right)\end{array}$} \\
\hline & Maximum & Minimum & & & & \\
\hline \multicolumn{7}{|c|}{2009} \\
\hline 22-30 May & 39.4 & 24.7 & 37.0 & 0 & 112 & 8.80 \\
\hline June & 40.0 & 25.2 & 45.0 & 111 & 334 & 9.90 \\
\hline July & 33.8 & 25.9 & 80.0 & 493 & 148 & 7.40 \\
\hline August & 34.8 & 26.9 & 77.0 & 118 & 141 & 6.60 \\
\hline September & 32.7 & 23.8 & 77.0 & 69.9 & 112 & 8.40 \\
\hline 1-17 October & 31.8 & 19.7 & 75.8 & 26.2 & 53 & 8.70 \\
\hline Mean & 35.5 & 24.4 & 65.3 & & & 8.34 \\
\hline Total & & & & 818 & 900 & \\
\hline \multicolumn{7}{|c|}{2010} \\
\hline 24-30 May & 40.1 & 24.7 & 44.0 & 3.80 & 106 & 9.30 \\
\hline June & 38.7 & 25.9 & 53.9 & 33.2 & 275 & 8.50 \\
\hline July & 32.7 & 26.9 & 81.0 & 382 & 131 & 4.40 \\
\hline August & 33.2 & 26.5 & 81.0 & 106 & 124 & 5.60 \\
\hline September & 31.7 & 23.5 & 82.0 & 127 & 98 & 6.80 \\
\hline 1-20 October & 32.9 & 21.1 & 73.6 & 0.00 & 58 & 5.50 \\
\hline Mean & 35.1 & 24.8 & 69.3 & & & 6.83 \\
\hline Total & & & & 652 & 792 & \\
\hline
\end{tabular}


University, Ludhiana and data recorded during rice growing seasons of 2009 and 2010 are given in Table 2. The reference evapotranspiration $\left(\mathrm{ET}_{\mathrm{o}}\right)$ was estimated by $\mathrm{ET}_{\mathrm{o}}$ calculator developed by $\mathrm{FAO}$ and available at http://www.fao.org/nr/water/eto.html.

The experimental data required for calibration and validation of the model was taken from the experiment described in detail by Sandhu et al., (2012). The experiment was conducted in split-plot design. The results of the treatment in which rice was transplanted in puddled flat plots receiving nitrogen @ $120 \mathrm{~kg} \mathrm{ha}^{-1}$ (recommended dose) in main plots and 4 irrigation schedules \{irrigation after 1 day $\left(\mathrm{I}_{1}\right), 2$ days $\left(\mathrm{I}_{2}\right), 3$ days $\left(\mathrm{I}_{3}\right)$ after water disappearance and at soil suction of $\left.150 \pm 20 \mathrm{~cm}\left(\mathrm{I}_{4}\right)\right\}$ in sub plots, were used for calibration and validation of the AquaCrop model. Rice variety PAU 201 was used for the experiment and it was transplanted on $28^{\text {th }}$ and $26^{\text {th }}$ June 2009 and 2010, respectively.

Description of AquaCrop model: The AquaCrop model developed by FAO simulates attainable yields of major herbaceous crops as a function of water consumption under rainfed and irrigated conditions. The growth engine of AquaCrop is water-driven, where transpiration is first calculated and translated into biomass using conservative, crop-specific parameters (Geerts et al., 2009). The water productivity parameter of AquaCrop is normalized for atmospheric evaporative demand and air $\mathrm{CO}_{2}$ concentration. The normalization is done to make AquaCrop applicable to diverse locations and seasons. This model uses canopy ground cover as a base to calculate transpiration and to separate soil evaporation from transpiration. Crop yield is calculated as the product of above-ground dry biomass and harvest index (HI). The HI can be modified negatively or positively, depending on stress level, timing and stress duration. The AquaCrop uses a relatively small number of parameters which are explicit and mostly intuitive and attempts to balance simplicity, accuracy and robustness. The detailed description of the AquaCrop model can be seen in Steduto et al. (2009).

Table 3. Non-conservative parameters used for simulation of rice growth and yield.

\begin{tabular}{ll}
\hline Parameter & Value \\
\hline Planting density plants ha $^{-1}$ ) & 333,333 \\
Initial canopy cover (\%) & 2.00 \\
Days taken by plants to recover from transplanting shock & 5.00 \\
Days taken from transplanting to reach maximum canopy cover & 60.0 \\
Days taken from transplanting to start of flowering & 63.0 \\
Total duration of flowering (days) & 15.0 \\
Days taken from transplanting to start of senescence of canopy cover & 97.0 \\
Days taken from transplanting to reach maturity & 107 \\
Maximum canopy cover (\%) & 95.0 \\
Canopy growth coefficient $\left(\%\right.$ day $\left.^{-1}\right)$ & 11.6 \\
Canopy decline coefficient $\left(\%\right.$ day $\left.^{-1}\right)$ & 9.30 \\
Maximum effective rooting depth (m) & 0.60 \\
Soil fertility & Non limiting \\
Soil bund height (m) & 0.30 \\
\hline
\end{tabular}




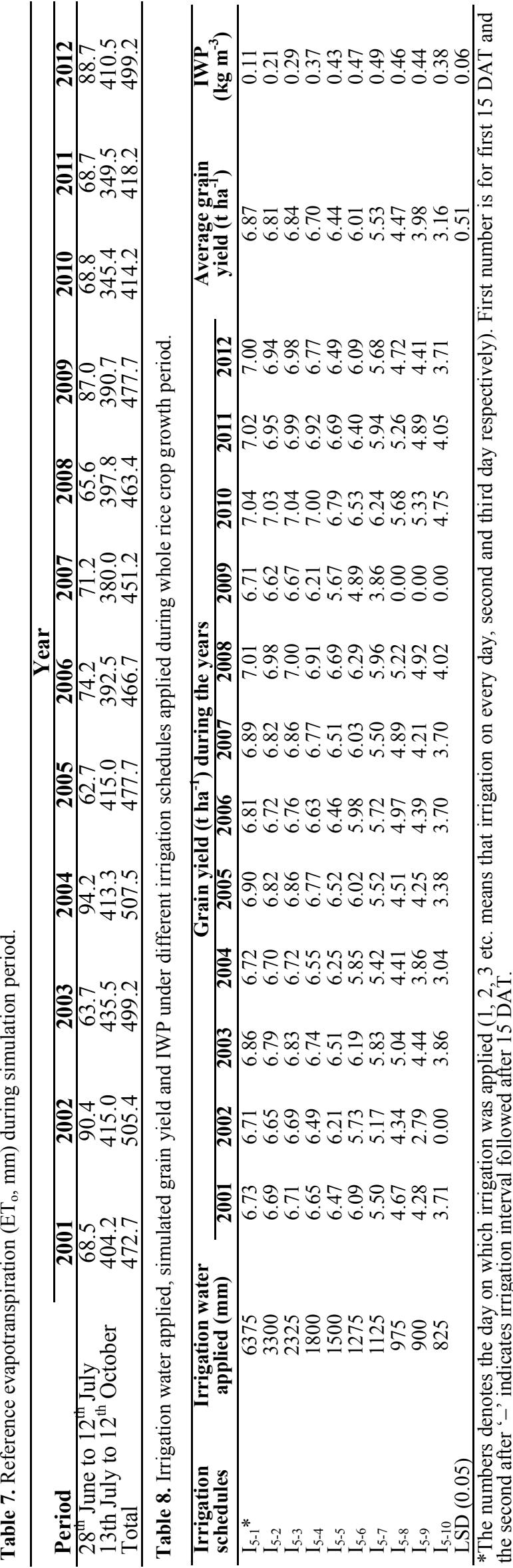


The AquaCrop model requires two types of input crop parameters. Values of crop specific but non location specific parameters have been determined and validated for varying locations by the FAO and are provided as default values in the model. These parameters are referred to as conservative parameters as they do not change with location, management practices and time and are applicable under stress free as well as under stress conditions. The second set of parameters are called non conservative parameters and are cultivar specific, affected by the climate, field management and conditions of the soil profile, thus have to be provided by the end user of the model.

The AquaCrop model differs from other models as it focuses on water, the use of ground canopy cover instead of leaf area index and the use of water productivity values normalized for atmospheric evaporative demand and of $\mathrm{CO}_{2}$ concentration. These differences enable the model for an extended extrapolation capacity to diverse locations and seasons, including future climate scenarios. Although the model is simple but it gives attention to the fundamental processes involved in crop productivity and in the responses to water, from a physiological and agronomic background (Raes et al., 2009).

Calibration of the model: The values of conservative parameters were used as already specified in the model. The non conservative parameters (Table 3) were calibrated from the measured data of the rice experiment conducted during 2009. The options available in the model were used to estimate the initial canopy cover $\left(\mathrm{CC}_{\mathrm{o}}\right)$ from plant density. The canopy expansion rates were automatically estimated by the model after specifying some of the phenological dates such as maximum canopy cover, senescence and maturity. The flowering date, length of the flowering stage, onset of senescence and maturity were specified to simulate the grain yield.

Under field management component of the model, a field was created surrounded by earthen bunds of 0.30 $\mathrm{m}$ height. The soil fertility level of the field was selected as non limiting (selected from the options available in the model) and it was not covered with the mulch. The amount of water applied during each irrigation in the field and simulation study was kept as 75 $\mathrm{mm}$.

The default soil profile (paddy soil) for the rice transplanted in the puddled field was of heavy clay type but the soil of field experimental site was loamy sand in texture. Therefore, a soil profile (Table 4) for puddled conditions was created by selecting the soil types from the list provided in the model along with their soil properties. Due to puddled field the top most horizon was taken as clayey and the values of water content at saturation (SAT), field capacity (FC), permanent wilting point (PWP), total available soil water (TAW) and tau (dimensionless drainage characteristic) were used as given in the model, but saturated hydraulic conduc- tivity $\left(\mathrm{K}_{\mathrm{sat}}\right)$ was taken as $41.8 \mathrm{~mm} \mathrm{day}^{-1}$. The measured value (measured by using constant head method) of $\mathrm{K}_{\mathrm{sat}}$ of top $0.05 \mathrm{~m}$ of puddled soil was $150 \mathrm{~mm}^{\text {day }}{ }^{-1}$, but this value did not represents the true condition of the field. If this value was used in the model, it resulted in the infiltration of the entire amount of the applied irrigation water on the day of irrigation itself and there was no ponded water left on the surface of the puddled soil on next day, but actually in the field sufficient water remained available during next day also. Therefore, the measured value of infiltration rate $\left(41.8 \mathrm{~mm} \mathrm{day}^{-1}\right)$ was used at the place of $\mathrm{K}_{\text {sat }}$. This value reflected the correct picture of the field, as on the day of irrigation $41.8 \mathrm{~mm}$ of water infiltrated and rest was infiltrated on the next day, after taking care of crop evapotranspiration. The infiltration rate was measured by infiltrometer and the measurements were done thrice during the crop season and average value was taken for the modelling. The topmost layer of the soil profile was selected as clay because during puddling the soil particle (sand, silt and clay) get separated and settle after some time. In the course of settling the sand particle settle first followed by silt and at last clay particles settle. This process results in the formation of a less pervious clay layer at the top surface of the soil, resulting in reduced infiltration rate. The thickness of these layers depends upon the content of respective soil particles and the thickness of clay layer in our experimental field was about $0.005 \mathrm{~m}$. Another problem was faced while creating the soil profile. If the depth of top clay layer was kept less than $0.05 \mathrm{~m}$ than all the applied irrigation water infiltrated on the day of irrigation itself. Therefore, we increased the thickness upto $0.05 \mathrm{~m}$ of clay layer, which is unrealistic in fields having loamy sand soil, but it served the purpose of retaining water on the surface of the field, which actually happens in puddled fields.

Validation of model: Model validation is an important step in crop modelling; it makes the user aware about how efficiently the model is working under different environment. The performance of the model was evaluated by using the parameters/ indexes given in the following sections. The experimental data of 2010 which was not used for calibration of the model was used for calculation of these parameters/ indexes and for validation of the model.

Coefficient of residual mass: Coefficient of residual mass (CRM) shows the difference in observed and predicted data relative to the observed data (Equation 1). Its zero, negative and positive values indicates a perfect fit, over and under-prediction, respectively. It was calculated as under

$\mathrm{CRM}=\left(\sum_{i=1}^{n} O_{i}-\sum_{i=1}^{n} P_{i}\right) / \sum_{\mathrm{i}=1}^{\mathrm{n}} \mathrm{O}_{\mathrm{i}}$

Where, $O$ is observed value and $P$ is value predicted by the model.

Root mean square error: The root mean square error (RMSE) provides the weighted variations in errors (residual) between the predicted and observed values. 
The value equal to zero for a model shows a perfect fit between the observed and predicted data. It was calculated as follows (Equation 2):

$\mathrm{RMSE}=\left[\sum_{i=l}^{n}\left(P_{i}-O_{i}\right)^{2} / n\right]^{0.5}$

Where, $P$ is value predicted by the model, $O$ is observed value and $n$ is total number of observations.

Normalised root mean square error: Normalized root mean square error (NRMSE) provides a measure $(\%)$ of relative difference of predicted versus observed data (Equation 3). The simulation is considered excellent, good, fair and poor if NRMSE is less than $10 \%$, $10-20 \%, 20-30 \%$ and more than $30 \%$, respectively, (Jamieson et al., 1991). NRMSE was calculated as follow:

NRMSE $=\left[\sum_{i=1}^{n}\left(P_{i}-O_{i}\right)^{2} / n\right]^{0.5} \times 100 / \bar{O}$

Where, $P$ is value predicted by the model, $O$ is observed value, $n$ is total number of observations and $\bar{O}$ is mean of observed values.

Mean absolute error: The mean absolute error (MAE) measures the weighted average magnitude of the absolute errors and was calculated as follows (Equation 4):

MAE $=\left[\sum_{i=1}^{n}\left|P_{i}-O_{i}\right|\right] / n$

Where, $P$ is value predicted by the model, $O$ is observed value and $n$ is total number of observations.

Mean bias error: The mean bias error (MBE) provides the information of over and under prediction by the model (Equation 5). Positive MBE indicate over prediction, negative values indicate under prediction and a zero indicates equal distribution between negative and positive values. The MBE was calculated as follows:

$\mathrm{MBE}=\left[\sum_{i=l}^{n}\left(P_{i}-O_{i}\right)\right] / n$

Where, $P$ is value predicted by the model, $O$ is observed value and $n$ is total number of observations.

Application of model: After the validation of the AquaCrop model, it was used for generation of irrigation schedule for rice transplanted in puddled soil. In Punjab (NW India) rice is grown in rainy season. Therefore, to study the effect of irrigation treatments in fields becomes difficult as at most of the time rains disturb the planned schedule of irrigations. To overcome this problem a rain data input file with no rain (zero seasonal rain) was created and used for running the model. This zero rain file was used in combination with other $\mathrm{ET}_{\mathrm{o}}$ and temperature files having actual values during the years 2001 to 2012 . ET o was calculated by using actual temperature, humidity, wind speed and duration of sunshine hours of the respective years. The model was run using the conservative and non conservative parameters (Table 3 ) along with zero rain and actual weather data of respective years.

The crop growth period of 107 days (after transplanting to maturity) was divided into two phases the first one was from transplanting to first 15 days and the remaining days were in the second phase. This was done to check the adequacy of a general recommendation of keeping water ponded during first 15 days after transplanting (DAT) of rice seedlings. The model was run during the respective years firstly to determine optimum irrigation schedule during first 15 DAT. The irrigation schedule varied from daily irrigation to irrigation on every $10^{\text {th }}$ day during the first fifteen days and daily irrigation during second phase of the crop growth. The best schedule having statistically similar grain yield as compared to $\mathrm{I}_{1-1}$ (daily irrigation during both phases) treatment along with higher IWP was selected. This selected irrigation schedule was further used for development of irrigation schedule for whole of the crop season (first and second phase). This was done by running the model with best irrigation schedule of first 15 days followed by irrigation schedules of $2^{\text {nd }}$ phase. The irrigation schedule of $2^{\text {nd }}$ phase also varied from irrigation on every day to irrigation on every $10^{\text {th }}$ day. The last irrigation during simulation was applied 15 days prior to harvest, because it is a common practice recommended to the farmers of the region. Irrigation water productivity $\left(\mathrm{kg} \mathrm{m}^{-3}\right)$ was calculated by dividing grain yield $\left(\mathrm{kg} \mathrm{ha}^{-1}\right)$ with irrigation water applied $\left(\mathrm{m}^{3} \mathrm{ha}^{-1}\right)$.

Statistical analysis: The output of model was subjected to statistical analysis using randomised block design (RBD). The years were assumed as replications and irrigation schedules as treatments. The means were compared using least significant difference (LSD) at $5 \%$, probability.

\section{RESULTS AND DISCUSSION}

\section{Model validation}

Periodic above ground dry biomass: The data on periodically observed and predicted above ground dry biomass of rice under different irrigation schedules during 2010 is presented in fig. 1. The model under estimated the above ground dry biomass at 30 DAT by $23.75,21.60,22.45$ and $24.85 \%$, in $\mathrm{I}_{1}, \mathrm{I}_{2}, \mathrm{I}_{3}$ and $\mathrm{I}_{4}$ irrigation schedules, respectively. The underestimation of above ground dry biomass of rice during initial phases of crop growth by AquaCrop is also reported by Lin et al. (2012). Afterwards it over estimated the biomass and the over estimation at harvest was 13.52, 14.13, 14.34 and $11.58 \%$, in $\mathrm{I}_{1}, \mathrm{I}_{2}, \mathrm{I}_{3}$ and $\mathrm{I}_{4}$ treatments, respectively. In all treatments, the predicted above-ground dry biomass agrees well with observed values, notwithstanding a slight under / overestimation by the model. These discrepancies might have been caused by error in measured data and/or the manner in which the model simulates crop growth. In AquaCrop model above ground dry biomass is derived from the crop transpiration by means of the crop water productivity (Steduto et al., 2009). However, in all the treatments the pattern of accumulation of predicted above ground dry biomass was very much similar to the observed pattern. The predicted rate of dry matter accumulation was quite similar with that of observed rate as indicated by the almost similar slopes of the curve in different sections. Above ground dry biomass at harvest: The CRM indicated an overestimation of above ground dry 

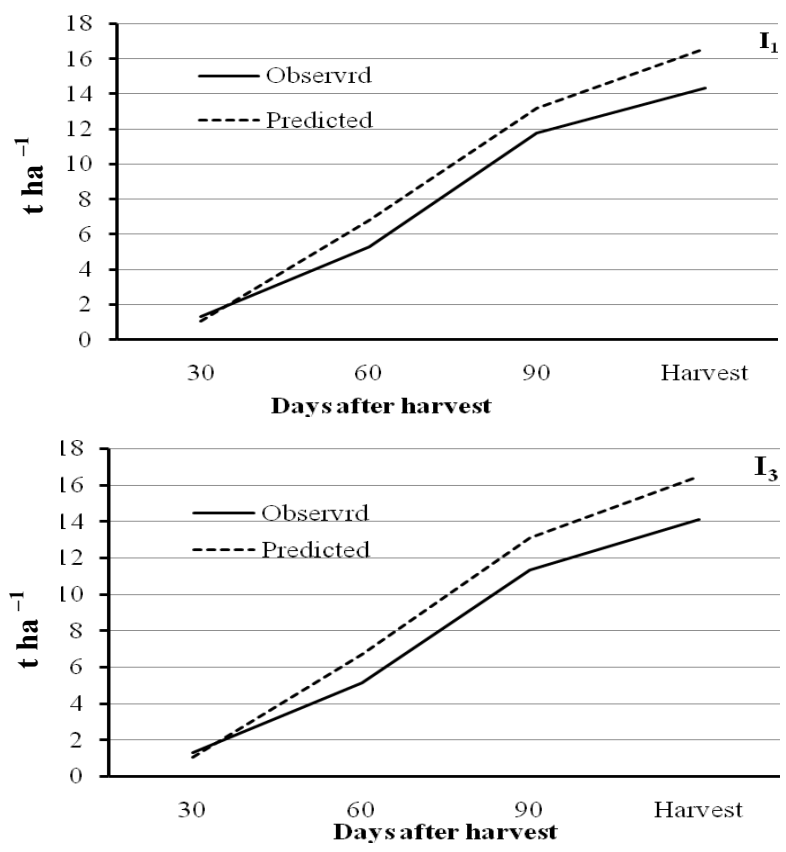
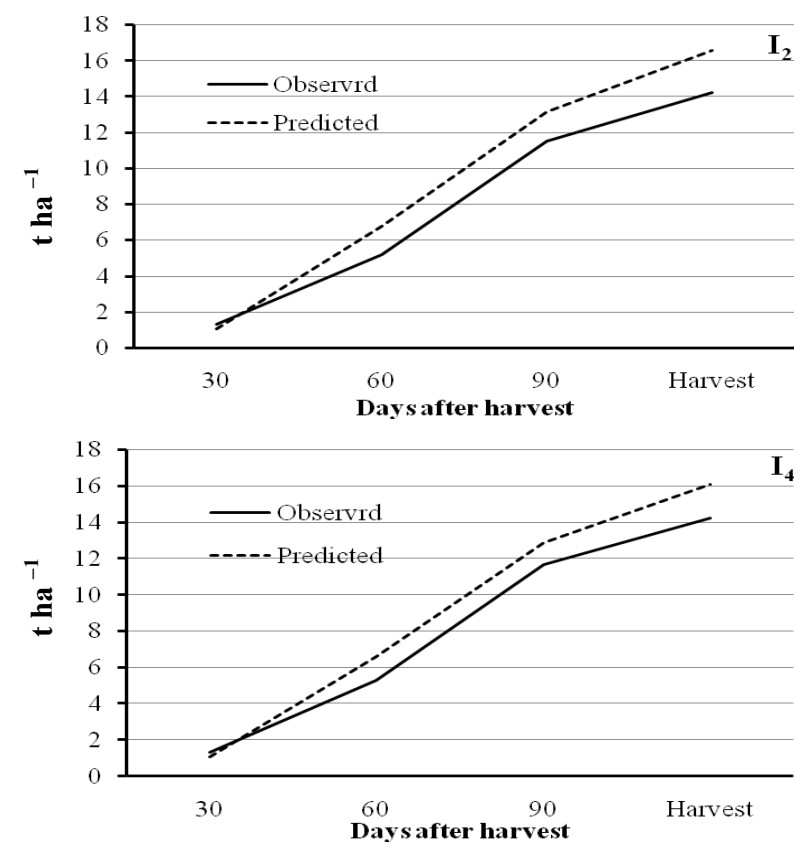

Fig.1. Observed and predicted above ground dry biomass of rice under different irrigation schedules during 2010.

biomass at harvest by a fraction of 0.15 in relation to the observed data (Table 5). The RMSE, MAE and MBE calculated for comparison of predicted values to the observed data shows the overestimation by the model upto $2.20 \mathrm{t} \mathrm{ha}^{-1}$. However, the NRMSE having value of $15.54 \%$ indicates a good agreement between the predicted and observed data.

Grain yield: The CRM for grain yield again pointed towards an overestimation by a fraction of 0.03 as compared to observed grain yield (Table 5). The RMSE, MAE and MBE had values of $0.23,0.21$ and 0.18 , respectively, indicating an overestimation by $2.47 \%$ (on average basis) or upto $0.23 \mathrm{t} \mathrm{ha}^{-1}$. Araya et al. (2010a) simulated barley grain yield by using AquaCrop and reported that the simulated grain yield deviated from the observed yield within a range of $-13 \%$ to $15 \%$. Zeleke et al. (2011) simulated total biomass and grain yield for canola (B. napus L.) using AquaCrop model and reported a $<10 \%$ difference between observed and simulated values. The value of NRMSE was $3.34 \%$ indicating an excellent agreement between the predicted and observed grain yield data.

Application of the model: After validation, the AquaCrop model was used for generation of irrigation schedule, having yield comparable to well watered treatment along with higher IWP. The data in Table 6 indicated that grain yield of rice did not decrease significantly upto an irrigation schedule of irrigating rice on every $5^{\text {th }}$ day $\left(\mathrm{I}_{5-1}\right)$ during first 15 DAT as compared to irrigation schedules having higher water inputs. Moreover, $\mathrm{I}_{5-1}$ had statistically similar IWP as compared to treatments having higher irrigation input. Therefore it is the best irrigation schedule for first phase of crop growth. Under Punjab conditions earlier it was recommended to the farmers to keep water ponded for getting higher weed control efficiency of the applied herbicides, which were mostly pre emergence in nature. Presently, post emergence herbicides are also available in rice so irrigation schedule of $\mathrm{I}_{5-1}$ can be recommended to the farmers after validating it under the actual field conditions.

During some years, the grain yield dropped down to zero (Table 6), with increasing irrigation interval, but remained non zero in some of the years even on irrigating rice on every $10^{\text {th }}$ day. This variation is due to the difference in total amount of $\mathrm{ET}_{\mathrm{o}}$ (Table 7) during the $1^{\text {st }} 15 \mathrm{DAT}$, except in year 2003 where $\mathrm{ET}_{\mathrm{o}}$ was low but yield dropped to zero when irrigation was applied on every $7^{\text {th }}$ day. The years having higher value of $\mathrm{ET}_{0}$ required frequent irrigation and vice versa.

The irrigation schedule for the remaining phase of the crop was generated by taking irrigation schedule of $\mathrm{I}_{5-1}$ for first 15 DAT and then following different irrigation schedules of $2^{\text {nd }}$ phase. The results (Table 8 ) indicated that on an average grain yield of rice was statistically similar between irrigation schedules of irrigating on every $\left(\mathrm{I}_{5-1}\right), 2^{\text {nd }}\left(\mathrm{I}_{5-2}\right), 3^{\text {rd }}\left(\mathrm{I}_{5-3}\right), 4^{\text {th }}\left(\mathrm{I}_{5-4}\right)$ and $5^{\text {th }}$ day $\left(\mathrm{I}_{5-5}\right)$. Out of these irrigation schedules $\mathrm{I}_{5-5}$ had statistically higher IWP.

Therefore, we can irrigate transplanted rice on every $5^{\text {th }}$ day during both phases of the crop growth in order to save irrigation water, have higher IWP and along with crop productivity comparable with that obtained with higher irrigation inputs. Before recommending this irrigation schedule to the farmers it needs to be evaluated in field, because it seem that transplanted rice seedlings may not survive if irrigated on every $5^{\text {th }}$ day during first 15 DAT. However, this study finds favour from another field study (Sandhu et al., 1980) conducted at same institute. The study found a non significant difference between grain yield obtained from continuous submergence, irrigation after 1, 2, 3 
and 5 days after disappearance of ponded water, but the soil of the experimental field was sandy loam and these treatments were started after 3 weeks of initial submergence. The average ( 4 year trial) irrigation water applied to treatment of irrigating 3 and 5 days after disappearance of ponded water was 1130 and $960 \mathrm{~mm}$, respectively and the average rainfall was $449.5 \mathrm{~mm}$. In present simulation study, treatment $\mathrm{I}_{5-5}$ needed 1500 mm of irrigation water (Table 8 ) in a rain free environment. The difference in total water input between the simulation and field study (Sandhu et al.,1980) may be due to the reason that the varieties used was of longer duration than used in simulation, initial ponding for three weeks and uneven distribution of rainfall. The results of the present study also find support from the reports like irrigating rice after 5 days after disappearance of ponded water (Singh et al., 2008), irrigation on every $5^{\text {th }}$ (Katozi et al., 2009) and $7^{\text {th }}$ (Khalifa et al., 2005) day. Sandhu et al. (1980) has also suggested that increasing the interval between successive irrigation leads to saving of irrigation water primarily due to reduction in seepage losses.

\section{Conclusion}

The study concluded that AquaCrop model simulated above ground dry biomass and grain yield of rice was quite satisfactorily. The values of NRMSE were $15.54 \%$ (within the range specified for good simulation) and 3.34\% (within the range specified for excellent simulation) for above ground dry biomass and grain yield, respectively. In the application part model indicated that there is no need to keep water ponded during first 15 days. These predictions of AquaCrop model needs to be verified under field conditions. The model suggested to irrigate the rice transplanted in puddled loamy sand soil on every $5^{\text {th }}$ day to get statistically higher IWP and statistically similar grain yield as obtained with higher irrigation water inputs. This irrigation schedule can be followed throughout the crop growth period of rice after its transplanting.

\section{REFERENCES}

Abedinpour, M., Sarangi, A., Rajput, T.B.S., Singh, M., Pathak, H. and Ahmed, T. (2012). Performance evaluation of AquaCrop model for maize crop in a semi-arid environment. Agric. Water Manag., 110: 55-66.

Alizadeh, H.A., Nazari, B., Parsinezhad, M., Ramazani, E.H. and Janbaz, H.R. (2010). Evaluation of AquaCrop model on wheat deficit irrigation in Karaj area. Iranian J. Irri. Drain, 4: 273-283.

Andarzian, B., Bannayan, M., Steduto, P., Mazraeh, H., Barati, M.E., Barati, M.A. and Rahnama, A. (2011). Validation and testing of the AquaCrop model under full and deficit irrigated wheat production in Iran. $A g-$ ric.Water Manag., 100: 1-8.

Araya, A., Habtub, S., Hadguc, K.M., Kebedea, A. and Dejened, T. (2010a). Test of AquaCrop model in simulating biomass and yield of water deficient and irrigated barley (Hordeum vulgare). Agric. Water Manag., 97:
$1838-1846$.

Araya, A., Keesstra, S.D. and Stroosnijder, L. (2010b). Simulating yield response to water of Teff (Eragrostis tef) with FAO's AquaCrop model. Fld. Crops Res., 116: 196-204.

Bali, A.S. and Uppal, H.S. (1999). Growth and yield dynamics of basmati rice in relation to intervals and cut-off dates of irrigations on loamy sand soils of Punjab. Appl.Biol.Res., 1: 63-66.

Baumhardt, R.L., Staggenborg, S.A., Gowda, P.H., Colaizzi, P.D. and Howell, T.A. (2009). Modelling irrigation management strategies to maximize cotton lint yield and water use efficiency. Agron. J., 101: 460-468.

Benli, B., Pala, M., Stockle, C. and Oweis, T. (2007). Assessment of winter wheat production under early sowing with supplemental irrigation in a cold high land environment using CropSyst simulation model. Agric. Water Manag., 93: 45-53.

Blum, F A. (2009). Effective use of water (EUW) and not water-use efficiency (WUE) is the target of crop yield improvement under drought stress. Fld. Crops Res., 112: 119-123.

Doorenbos, J. and Kassam, A.H. (1979). Yield response to water. FAO irrigation and drainage paper no. 33. FAO, Rome, Italy, $193 \mathrm{pp}$.

Edwin, L. and Anal, P.S.M. (2008). Effect of irrigation regimes and nitrogen management practices on uptake of nutrients and grain yield in hybrid rice (Oryza sativa L.). Envir. Eco., 26: 1146-1148.

Geerts, S. and Raes, D. (2009). Deficit irrigation as on-farm strategy to maximize crop water productivity in dry areas. Agric. Water Manag., 96:1275-1284.

Geerts, S., Raes, D., Garcia, M., Miranda, R., Cusicanqui, J.A., Taboada, C., Mendoza, J., Huanca, R., Mamani, A., Condori, O., Mamani, J., Morales, B., Osco, V. and Steduto, P. (2009). Simulating yield response of Quinoa to water availability with AquaCrop. Agron. J., 101: 499-508.

Heng, L.K., Asseng, S., Mejahed, K., and Rusan, M. (2007). Optimizing wheat productivity in two rainfed environments of the west Asia-North Africa region using a simulation model. European Journal of Agronomy, 26: 121-129.

Heng, L.K., Hsiao, T., Evett, S., Howell, T. and Steduto, P. (2009). Validating the FAO AquaCrop model for irrigated and water deficient field maize. Agron. J., 101: 488-498.

Husain, M.F., Mohd Shamim and Pal, S. (2008). Influence of irrigation schedule on yield and water use efficiency of rice (Oryza sativa) in kharif season. Int. J. Agric.Sci., 4: 332-334.

Jamieson, P.D., Porter, J.R. and Wilson, D.R. (1991). A test of computer simulation model ARC-WHEAT1 on wheat crops grown in New Zealand. Fld. Crops Res., 27: $337-350$.

Katozi, M., Khoei, F.R. and Sabouri, H. (2009). Effect of irrigation management on grain filling rate, grain filling duration and leaf relative water content on three rice (Oryza sativa L.) cultivars. J. Sci. Tech. Agric. Nat. Res., 13: 623-638.

Khalifa, A.A.A., Salem, A.K.M., and El Refaee, I.S. (2005). Effect of irrigation intervals and nitrogen sources on yield, sugar and starch content of rice. Egyptian J. Agron., 27: 113-123. 
Lin, L., Zhang, B. and Xiong, L. (2012). Evaluating yield response of paddy rice to irrigation and soil management with application of the AquaCrop model. Transactions of the ASABE, 55: 839-848.

Luikham, E., Krishnarajan, J. and Premsekhar, M. (2004). Irrigation and nitrogen application schedules for hybrid 'ADTRH 1' rice (Oryza sativa) in Tamil Nadu. Indian $J$. Agron., 49: 37-39.

Merwin, H.D. and Peech, M. (1950). Exchangeability of soil potassium in the sand, silt and clay fractions as influenced by the nature of the complementary exchangeable cations. Pro. Soil Sci. Soc. America, 15: 125-128.

Mkhabela, M.S. and Bullock, P.R. (2012). Performance of the FAO AquaCrop model for wheat grain yield and soil moisture simulation in Western Canada. Agric. Water Manag., 110: 16-24.

Olsen, S.R., Cole, C.V., Waternabe, F.S. and Dean, L.A. (1954). Estimation of available phosphorus in soils by extraction with sodium bicarbonate. USDA Circular, 939: 19.

Parihar, S.S. (2004). Effect of crop-establishment method, tillage, irrigation and nitrogen on production potential of rice (Oryza sativa)-wheat (Triticum aestivum) cropping system. Indian J. Agron., 49: 1-5.

Pereira, L.S., Paredes, P., Sholpankulov, E.D., Inchenkova, O.P., Teodor, P.R. and Horst, M.G. (2009). Irrigation scheduling strategies for cotton to cope with water scarcity in the Fergana Valley, Central Asia. Agric. Water Manag., 96: 723-735.

Raes, D., Steduto, P., Hsiao, T.C. and Fereres, E. (2009). Reference Manual, Chapter 1 - AquaCrop, January 2009 available at http://www.fao.org/NR/water/docs/ AquaCropChapter1.pdf, cited on 1-2-2013.

Ramakrishna, Y., Singh, S. and Parihar, S.S. (2007). Influence of irrigation regime and nitrogen management on productivity, nitrogen uptake and water use by rice (Oryza sativa). Indian J. Agron., 52: 102-106.

Sandhu, B.S., Khera, K.L., Prihar, S.S. and Singh, B. (1980). Irrigation needs and yield of rice on a sandy loam soil as affected by continuous and intermittent submergence. Indian J. Agric. Sci., 50: 492-496.

Sandhu, S.S., Mahal, S.S., Vashist, K.K., Buttar, G.S., Brar, A.S., and Maninder Singh (2012). Crop and water productivity of bed transplanted rice as influenced by various levels of nitrogen and irrigation in northwest India. Agric. Water Manag., 104: 32-39.

Sharma, P.K., Bhushan, L., Ladha, J.K., Naresh, R.K.,
Gupta, R.K., Balasubramanian, B.V. and Bouman, B.A.M. (2002). Crop-water relations in rice-wheat cropping under different tillage systems and water management practices in a marginally sodic, medium textured soil, in: Bouman B.A.M., Hengsdijk H., Hardy B., Bindraban P.S., Tuong T.P. and Ladha J.K. (Eds.), Water-Wise Rice Production. I.R.R.I., Los Banos, Philippines, pp. 223-35.

Singh, A.K., Choudhury, B.U. and Bouman, B.A.M. (2002). Effects of rice establishment methods on crop performance, water use and mineral nitrogen, in: Bouman B.A.M., Hengsdijk H., Hardy B., Bindraban P.S., Tuong T.P. and Ladha J.K. (Eds.), Water-Wise Rice Production. I.R.R.I., Los Banos, Philippines, pp. 237-46.

Singh, R., Kumar, A., Kumar, S. and Chand, R. (2008). Alternative crop establishment tillage technologies in rice. Indian Res. J. Ext. Edu., 8: 13-15.

Singh, K. (2006). Fall in water table in central Punjab how serious? Tech. bull. The Punjab State Farmers Commission. Government of Punjab, Mohali, Punjab, India, pp. 10.

Steduto, P., Hsiao, T.C., Raes, D., and Ferereset, E. (2009). AquaCrop - the FAO crop model to simulate yield response to water: I. Concepts and underlying principles. Agron. J., 101: 426-437.

Stricevic, R., Cosic, M., Djurovic, N., Pejic, B. and Maksimovic,L.(2011). Assessment of the FAO AquaCrop model in the simulation of rainfed and supplementally irrigated maize, sugar beet and sunflower. Agric. Water Manag., 98: 1615-1621.

Subbiah, B.V. and Asija, G.L. (1956). A rapid procedure for the estimation of available nitrogen in soils. Curr. Sci., 25: $259-260$

Tuong, T.P. and Bouman, B.A.M. (2003). Rice production in water scare environments, in: Kijne, J.W., Barker, R., Molden, D. (Eds.), Water Productivity in Agriculture: Limits and Opportunities for Improvement, C.A.B.I. Publishing, Wallingford, U.K., pp. 53-67.

Walkley, A. and Black, C.A. (1934). An examination of the Degtjareff method for determining soil organic matter and a proposed modification of the chromic acid titration method. Soil Sci., 37: 27-38.

Zeleke, K.T., Luckett, D. and Cowley, R. (2011). Calibration and testing of the FAO AquaCrop model for canola. Agron. J., 103: 1610-1618.

Zinyengere, N., Mhizha, T., Mashonjowa, E., Chipindu, B., Geerts, S. and Raes, D. (2011). Using seasonal climate forecasts to improve maize production decision support in Zimbabwe. Agric. Forest Met., 151: 1792-1799. 